\title{
The socio-economic contribution of Detarium senegalense seeds to rural livelihoods in Togo (West Africa)
}

\author{
Fifonsi Ayélé DANGBO ${ }^{1 *}$, Kossi ADJONOU ${ }^{1}$, Kouami KOKOU ${ }^{1}$ et Juergen BLASER ${ }^{2}$ \\ ${ }^{1}$ Laboratoire de recherche forestière, Faculté des Sciences, Université de Lomé, BP 1515 Lomé, Togo. \\ ${ }^{2}$ School of Agricultural, Forest and Food Sciences, Bern University of Applied Science (HAFL), Switzerland. \\ *Auteur correspondant; E-mail: fifonsidangbo@gmail.com
}

\section{ACKNOWLEDGEMENTS}

The authors would like to express sincere thanks to African Forest Forum (AFF) for their financial support to this work.

\begin{abstract}
Detarium senegalense J. F. Gmel., of the Fabaceae family, is one of the most used tree species in the natural forest area of Togo. The rural population uses several parts of the species to enhance their income. Detarium senegalense provides in particular a high economic valued seed. However, there are only few scientific studies on the contribution of the species to the income of rural households. The objective of this study is to contribute to the promotion of multi-purpose tree species in Togo with particular emphasis on better knowledge of Detarium senegalense. The methodology used is based on semi-structured interviews as well as participatory observations. Detarium senegalense contributes to the economy and livelihood of the rural population through income generated by the collection and trading of seeds. Collectors and traders of the seed are mostly women. The average amount of seed harvested is $45.6( \pm 25.3) \mathrm{kg}$ per year per collector and revenue per year per collector is US \$ $59( \pm 58)$. Local people can have an important role to secure Detarium senegalense in the degraded natural forests of Togo. However, the sustainable management of this species in the future can only be secured through an active promotion of natural regeneration, enrichment planting and domestication.
\end{abstract}

(C) 2019 International Formulae Group. All rights reserved

Keywords: Detarium senegalense, seed harvesting, impact, rural income, Togo.

\section{INTRODUCTION}

Non timber forest products (NTFPs) are an important component to rural livelihoods and make significant and timely income contributions to poor households (Malleson et al., 2014). Many studies have revealed the socio-economic value of these resources such as those from Adansonia digitata, Irvingia gabonensis / Irvingia wombolu, Dacryodes edulis, Ricinodendron heudelotii, Garcinia kola, Chrysophyllum albidum, Cola spp etc. to the national economy and livelihoods in West Africa (Timko et al., 2010; Heubes et al., 2012) ;
Neumann and Hirsch, 2000; Belcher and Vantomme, 2003; Bayeli et al., 2019; Balde et al., 2019). They are particularly important for ensuring food security and maintaining nutritional balance in the diet of populations. NTFPs contribute to the annual total household income. Observations range from $15 \%$ in Malawi to roughly $40 \%$ in Mali (Heubes et al., 2012). In many rural communities, especially in the dry tropics, people depend solely on agriculture and marketing of NTFPs for their income and subsistence (Agbelade and Onyekwelu, 2013). The poorest households in remote areas are 
most dependent on income from the collection of NTFPs as it represents one of the few opportunities to earn some money in those areas (Malleson et al., 2014). Income from NTFPs, particularly from species such as Arthocarpus sp, Canarium schweinfurthii, Dacryodes edulis, Gambeya Africana, Ricinodendron heudelotii, may become even more important to rural households in West Africa, as we move forward towards changeable and uncertain times, characterized by rapid and inequal economic growth, population expansion and an ever changing and unpredictable climate (Heubes et al., 2012). Some NTFPs are characterized by relatively low yields, but the importance of their contribution to reduce poverty is found in their role in reducing risk through a diversified livelihood strategy (Malleson et al. 2014). Among the forest tree species that produce a tradeable NTFP, Detarium senegalense JF Gmel is one of the most exploited species in West Africa, particularly in Togo (Atato et al., 2010). Since many years, the timber is exploited locally in Togo (Adjossou, 2009). Detarium senegalense produce fruits and their seeds have a high economical value. Detarium senegalense is a very popular fruit and its pulp is widely consumed in Senegal (Diop et al. 2010). In addition, the fruit also has therapeutic properties for treating coughs, kidney pain and leprosy (Diop et al., 2010). Detarium senegalense is used for its medicinal properties and sale of seeds is said to be economically promising (Atato et al., 2010). The pulp of Detarium senegalense (green) is used to relieve cough in Senegal and Guinea (Lykke, 2000). In Côte d'Ivoire and Guinea, they are used in local friction against the evils of chronic kidney and back pain (Ambé, 2001). Although there is little information on the nutritional composition of Detarium senegalense fruit, it seems to be a very healthy product (Ayessou et al., 2014). According to Diop et al. (2010), they are rich in nutrients. In Togo, the seeds are subject to international trade (Atato et al., 2010). The same authors have also shown that Detarium senegalense has become a highly sought species in the country and is the subject of collective harvest in which men are now involved (traditionally, this activity is done by women). However, as for most of NTFPs, data and statistics on
Detarium senegalense are scarce and often incomplete. For the rational management of the species and for developing restoration strategies, it is essential to find answers to some research questions about the availability of Detarium senegalense products for the local population in Togo and the economic contribution of Detarium senegalense seeds to their income. Despite the threat to the species, there are no up-to-date, reliable data on the use of seed and the survival of the species in Togo. To establish a good policy for the conservation of a species, this information is very important (Kebenzikato et al., 2014). The general objective of this study was to contribute to the promotion of multi-purpose tree species in Togo with particular emphasis on a better understanding of economic value of Detarium senegalense. The specific objectives are: (i) determine the availability of Detarium senegalense seeds for local population in Togo; (ii) evaluate the economic contribution of Detarium senegalense seeds to rural population around Togo's Atakora chain.

\section{MATERIALS AND METHODS}

\section{Site selection and sampling}

The selection of the study sites was done in two distinct phases. In the first phase, several villages being major sources of supply of Detarium senegalense were selected. In the second phase preliminary surveys (prospective study) were carried out to choose the interested villagers to study in terms of resources (Loubelo, 2012). The main criteria for village selection are (i) the geographical location of the village in relation to ecological zones for Togo: II (dry zone of the littoral), IV (forest zone) and V (southern coastal zone), (ii) the accessibility of local populations to forest containing Detarium senegalense and (iii) the harvesting and trade of the species seeds by the villagers. The data collected are from sixteen (16) villages located in Zone II and IV (Table 1). The villages were surveyed by targeting the major markets representing the main points of entry and trade of seeds. In order to estimate the quantities of seeds collected during a year, information was also collected from traders who used to sell seeds in rural markets. 


\section{Collection of socio-economic data}

Data collection was based on semistructured interviews as well as participator observations (Kothari, 2004; McLafferty, 2003). The semi-structured interviews were administered to 160 collectors and traders of Detarium senegalense seeds. A combination of closed and open questions was developed in order to obtain information from the collectors of Detarium senegalense seeds. These questions are related to the accessibility of the harvesting site of Detarium senegalense seeds, the quantity of seed harvested, the harvest period, the price and the income generated by the sale of Detarium senegalense seeds, the main actors, the exploitation of Detarium senegalense wood. The annual income derived from the sale of Detarium senegalense seeds was calculated for each interviewee on the basis of the average quantities of seeds sold as well as the market price. The socio-demographic characteristics of the people interviewed (age, occupation, sex) were also collected. Since interviewees may have difficulty recalling the exact amount of fruit harvested, the quantity of fruit reported by them may underestimate or overestimate the actual amount harvested (Heubes et al., 2012). To reduce the margin of error, some interviewees were followed in the fruit harvesting area to weigh the harvested seeds on site. An exploratory study was carried out in the month of January 2016 in Badou. The actual survey was conducted from March 6 to April 30, 2017. The investigative team consisted of two (2) persons including one (1) principal investigator and one (1) local interpreter. The surveys were conducted in local languages. The interviewees responded easily to the various questions asked because they were quickly reassured by the presence of the local interpreter in the team.

\section{Statistical analysis}

A descriptive statistic was used for the analysis of socio-economic data since the study is descriptive and explanatory. The Social Science Statistics Software (SPSS) version 12.0 for Windows was used for tabulation of completed questionnaires and socio-economic data processing. The data analysis was done under the Excel sheet.

The trade of Detarium senegalense is essentially organized in the informal sector and for this reason, the quantification of the seeds collected and sold is not easy. The unit of measurement for the seeds is the local bowl. To find out the weight (in $\mathrm{kg}$ ) of a bowl of Detarium senegalense, 10 bowls of the seed were weighed separately using a precision scale. Thus, the average weight of a bowl has been determined and equals to $3 \mathrm{~kg}$. The seeds of Detarium senegalense are available on the market from October to April according to ecological zones. The selling price depends on supply and demand, which is between US \$ 0.59 and US \$ 0.85 per kilogram. The average selling price is calculated from the average of the lowest and highest prices collected during the survey (Sounou et al. 2019). The average quantity of seeds harvested per collector is estimated by the formula: $\frac{\sum_{t=1}^{n} Q t}{n}$

Qt: quantity of Detarium senegalense harvested per collector; n: total number of collectors surveyed. The average income (Rm) per collector and per village was estimated by multiplying the average quantities of Detarium senegalense harvested $(\mathrm{Qm})$ at the average market price $(\mathrm{Pm})$. The formula of $\mathrm{Rm}$ is as follows: $\mathrm{Rm}=\mathrm{Qm} * \mathrm{Pm}$

The average income from the sale of Detarium senegalense seeds does not take into account the quantities consumed. This is because the seeds of Detarium senegalense are not consumed by the local population in Togo. Therefore, the quantity of seed collected is substantially equal to the quantity of seed sold. Also the average income from the sale of Detarium senegalense is compared to the per capita gross annual income of US \$ 406 in ecological zone II and US \$ 350 in ecological zone IV (Repubique du Togo, 2013). 
Table 1: Local name and level of knowledge of Detarium senegalense in different localities of the study site

\begin{tabular}{llllll}
\hline Localities & Zone & $\begin{array}{l}\text { Number of collectors } \\
\text { and traders }\end{array}$ & $\begin{array}{l}\text { Local name } \\
\text { Detarium senegalense }\end{array}$ & $\begin{array}{l}\text { Level of knowledge of } \\
\text { the species (\%) }\end{array}$ \\
\hline Fazao & II & 26 & Agbakpa/ Agbakpateo & 80 \\
\hline Hezoude & II & 15 & kpoye & 90 \\
\hline Solimde & II & 11 & kpoye & 90 \\
\hline Brefou & IV & 10 & kpekpe & 80 \\
\hline Akakope & IV & 11 & kpekpe & 80 \\
\hline Kougnohou & IV & 12 & kpekpe & 95 \\
\hline Avegame & IV & 10 & kpekpe & 90 \\
\hline Afereh & IV & 7 & kpekpe & 95 \\
\hline Djonatikassa & IV & 7 & kpekpe & 98 \\
\hline Enyawale & IV & 6 & kpekpe & 90 \\
\hline Kemoze & IV & 8 & kpekpe & 95 \\
\hline Efoukpa & IV & 7 & kpekpe & 95 \\
\hline Nyawali & IV & 8 & kpekpe & 90 \\
\hline Ave maria & IV & 6 & kpekpe & 90 \\
\hline Lomnava & IV & 6 & kpekpe & 90 \\
\hline Badou & IV & 10 & Kpekpe/ Akpa & 95 \\
\hline
\end{tabular}

\section{RESULTS}

Knowledge of Detarium senegalense in the study area

The people surveyed $(12 \%$ men and $88 \%$ women) age range is between 25 to 55 years. This age group is justified by the fact that for most of the case, these categories of people is mainly involved in the activities of valorization and marketing of NTFPs such as those from Detarium senegalense in several regions across the country. The high rate of women is explained by the fact that they are the main managers of natural resources. According to the information obtained, seeds trade began in the year 2000 by Nigerians who discovered seed supply sites in Togo.
In the villages of zone II (Fazao, Hezoude, Solimde), villages near the Fazao Malfakassa national park, the seeds of Detarium senegalense are collected illegally because access to the park is prohibited to the local population. In the villages of zone IV (Brefou, Akakopé, Kougnohou, Avegame, Afereh, Djonatikassa, Enyawale, Kemoze, Efoukpa, Nyawali, Ave Maria, Lomnava), the populations have easy access to the seed collection area. Indeed, Detarium senegalense trees are found in rural areas in the degraded natural forest areas, and scattered in coffee and cocoa plantations (Figure 1). 
The information collected in different villages on the knowledge of the species is not identical (Table 1). In the area of Badou (zone II), more than $90 \%$ of all the people surveyed claim to have a good knowledge of Detarium senegalense. In that zone, different local names are given to the seeds of Detarium senegalense namely "Kpekpe" or "Akpa" or "the seed of Nigeria" because of its trade which is much oriented towards Nigeria. With regard to the area around the sacred "Have forest" (in zone V), the people surveyed have no knowledge of the use of seeds and other parts of the species. They are totally unaware that the seeds of Detarium senegalense have any use. The surveys in the sacred forest of "Have" have made it possible to note the presence of the species feet in that zone. Surveys have shown that Detarium senegalense is used in the area of forest of "Have" as timber and for wood energy (charcoal). In order to facilitate the transport of seeds, collectors generally decorticate the fruits in the forest to remove the seeds.

Conflicts of interest usually break out between Detarium senegalense fruit collectors and plantation owners in some areas. In zone $\mathrm{IV}$, the feet of the species are generally located in coffee and cocoa plantations. In these areas, seeds are collected in general by the plantation owners. However, clandestine intrusions into the plantations for seed harvesting are sometimes noted. According to the respondents, the owners who cannot benefit from the sale of seeds used to cut the trees in the majority of cases. In the villages surrounding the Fazao National Park the problem did not arise. On the other hand, there is a certain solidarity between the collectors given the fact that access to the collection points is prohibited and is done clandestinely.

\section{Techniques and frequency of Detarium senegalense seeds harvesting Availability period of Detarium senegalense seeds}

More than $90 \%$ of surveyed claim that flowering occurs from February to May. After flowering, fruits take about 5 to 6 months to mature. The seeds are available on the market from October to April depending on the area. It is possible to find the seeds on the market in May especially with collectors who had stocked seeds.

\section{Accessibility to harvesting areas and harvesting techniques}

Access to the harvesting areas is easy in Akposso, Akebou and Badou and is not subject to any authorization. Thus, according to the interviewees, during the fruiting period, the collectors start by prospecting in the fields and areas where Detarium senegalense exist to monitor the trees. It is at the stage of maturity that the fruits begin to fall from the trees and the harvest is done by the collection of fruits on the ground. In Badou, $80 \%$ of the interviewees reported that they used to go to the forest and to the fields sometimes very early in the morning ( 3 am or 4 am) to maximize the fruit harvest. In Zone IV, 75\% of the population estimate the travel time to two (2) hours of walking. This is explained by the fact that the harvesting areas, generally cocoa/coffee plantations (Figure 2) are quite close to the villages. In the villages surrounding Fazao National Park (Zone II) the seeds of the collected species are carried on the head. More than $90 \%$ of those interviewed in Fazao report spending eight (8) hours per trip to collect Detarium senegalense seeds. In that region, the collection area which is the National Park is very far from villages and the local population used to walk almost ten kilometers to collect seeds (Photo 1).

According to the information obtained, the fruit harvesting activity is tedious, and the collectors are preferably associated in small groups of two to three people in order to be able to collect the maximum of fruit and share the income after the sale of the seeds. The fruits harvested by collectors are then sold to the intermediate traders who can make the storage. These intermediate traders decorticate the fruits with the cutter (Photo 2) and seeds are sold to wholesale traders who are generally Nigerians. These seeds are no longer processed further before being exported to Nigeria. 


\section{Average quantity of seeds collected}

The average quantity of seeds collected per collector varies considerably between villages. This quantity seems to be determined by the quantity which can be carried on the head at home by a collector during a single return trip. The average amount of seeds per trip is $10 \mathrm{~kg}$. According to the information collected, the average quantity of seeds harvested is $45.62 \pm 25.31$ $\mathrm{kg}$ per year per collector. The villages bordering the national park (Fazao, Solimde and Hezoude) have the largest quantities of seeds harvested per collector (Figure 3). This can be explained by the fact that these villages do not have enough alternative sources of income. This drives them to collect non-timber forest products particularly Detarium senegalense seeds.

The average annual income from the sale of Detarium senegalense seeds varies considerably depending on the amount of seed harvested and the market price (US \$ $0.72 \pm 0.18$ per kilogram). This income is on average very low (Figure 3 ) compared to the gross annual income per capita of $\$ 406$ in ecological zone II and \$350 in ecological zone IV. The seed traders are usually the collectors. These revenues are more significant in Fazao, Hezoude and Solimde where fruit collection and sales activities are more important.

\section{Actors involved in marketing of Detarium senegalense seeds}

The harvesting and sale of Detarium senegalense seeds is in the informal sector. The main actors are collectors, traders, wholesalers and consumers. The harvesting period of Detarium senegalense fruits is in average, three (3) months during the year. Therefore, the trade of Detarium senegalense seeds is a secondary activity for these collectors (Figure 4). The average annual income per collector is US \$59 \pm 58 depending on the amount of seed collected. Wholesalers are generally Nigerians who used to buy the seeds from the collectors. The average purchase price of seeds is US \$ $11000 \pm 5657$ per year. The average selling price of the species in Nigeria could not be collected. This would have allowed us to calculate the profit margin of the different actors involved in the value chain.

The actors of the sector face several constraints which are among others: - The high level of poverty and the nonconsumption of the species by local population in Togo. This is the reason why Detarium senegalense seeds are sold at prices imposed by buyers.

The lack of adequate transport infrastructure;

The lack of information at all levels, on the importance of Detarium senegalense in terms of benefits it can provide in Nigeria. This lack of information leads the actors to sell the seeds of the species at a very low price. Use of Detarium senegalense seeds

In the different study areas, the seeds of Detarium senegalense are not consumed by the local populations because they do not have any knowledge from the seeds value. An individual interview with ten (10) Nigerians wholesale buyers of the Detarium senegalense seeds provided additional information on the value chain of the species. According to these Nigerians, the quantity of seed purchased in Kougnohou area during the year 2016 was between 150 and 300 bags, meaning 10500 to $21000 \mathrm{~kg}$ of Detarium senegalense seeds.

The purchase price of the seed varies between 7000 and 15000 US \$ per year for the entire season, for trader. In addition, seeds sold on the market of Kougnohou do not come only from this locality but also from neighboring villages. Seeds bought on the markets in Togo are sold in Nigeria where they are used as sauce thickener. In year 2000 (beginning of Detarium senegalense seeds trade), the price of a kilogram of seed was between 2 and 3 US \$ depending on localities. Nowadays, the price has fallen on the market (US \$ 0.59 and US \$ 0.85 per $\mathrm{kg}$ ) because others seed supply locations have been discovered in other countries such as Cameroon and Guinea. 


\section{Other uses of Detarium senegalense}

In Zone IV, most of Detarium senegalense are located in forest relics that are mostly degraded natural forests, coffee plantations and cacao, the species is considered as owned by the land owner. In rare cases, Detarium senegalense is exploited as timber in ecological zone IV (Figure 5). Populations around Fazao Malfakassa Park (Fazo, Hezoude, Solimde) do generally not cut Detarium senegalense for timber or fuelwood. This is because trees of this species are generally found in the national park. However, there are clandestine intrusions in the area. The degree of removal of Detarium senegalense wood can be potentially important in some areas (Badou, Akakope, Kougnohou, Enyawale, Afereh) where the population is the owner of the forest land. Therefore, trees are scarce in those areas especially in Badou (Figure 5).

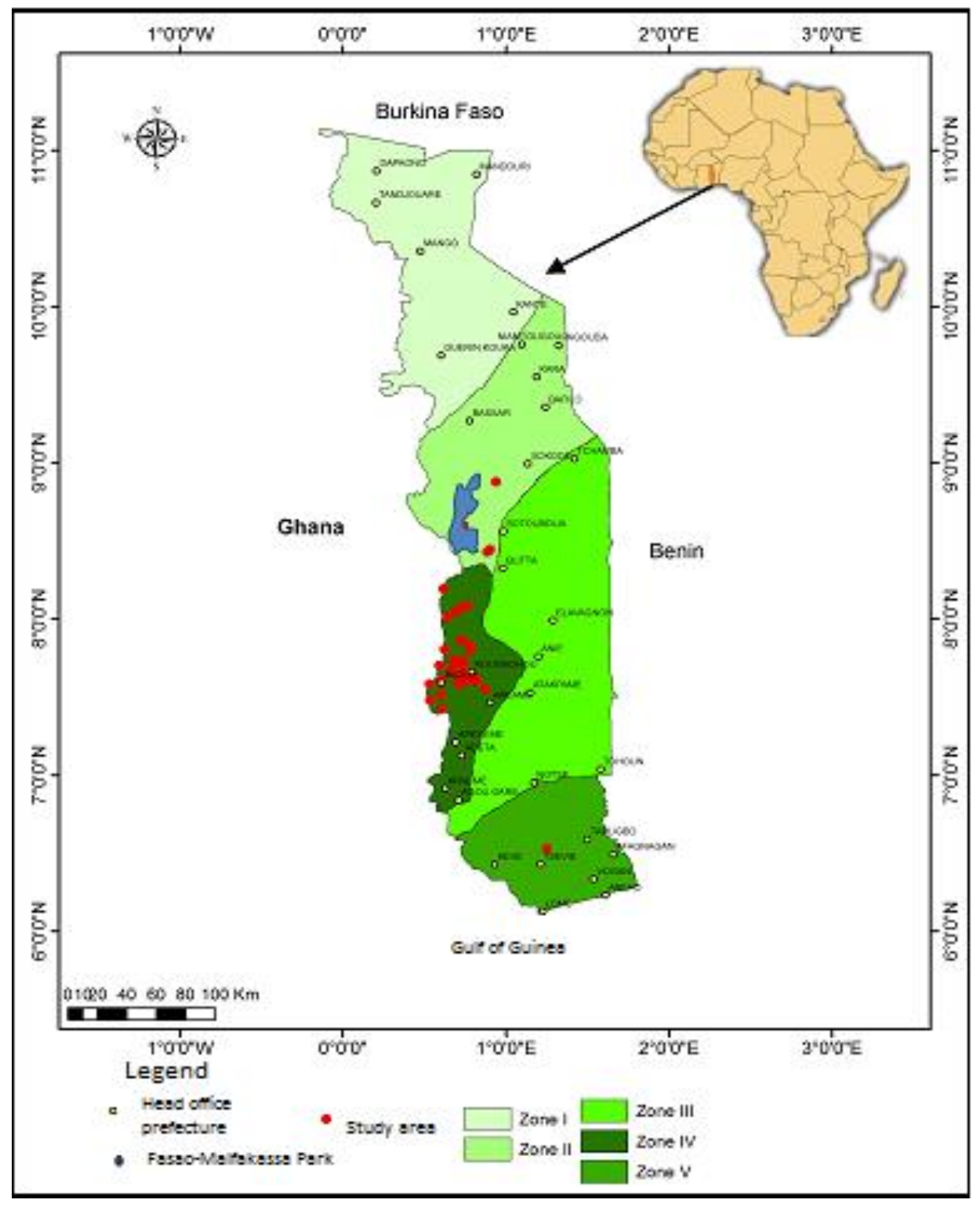

Figure 1 : Study area. 


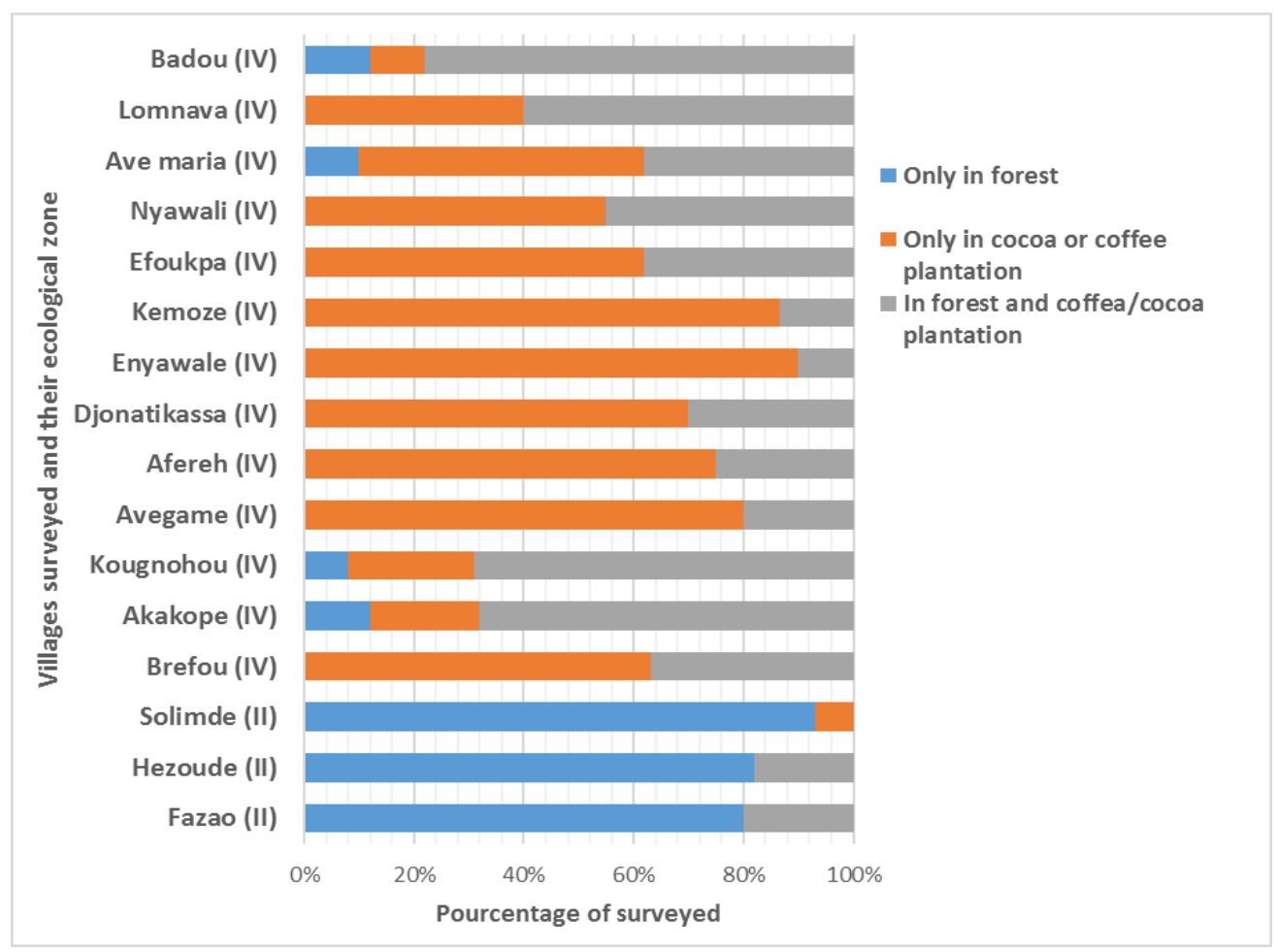

Figure 2: Main harvesting areas of Detarium senegalense seeds : (IV) stand for ecological zone IV; (II) stand for ecological.

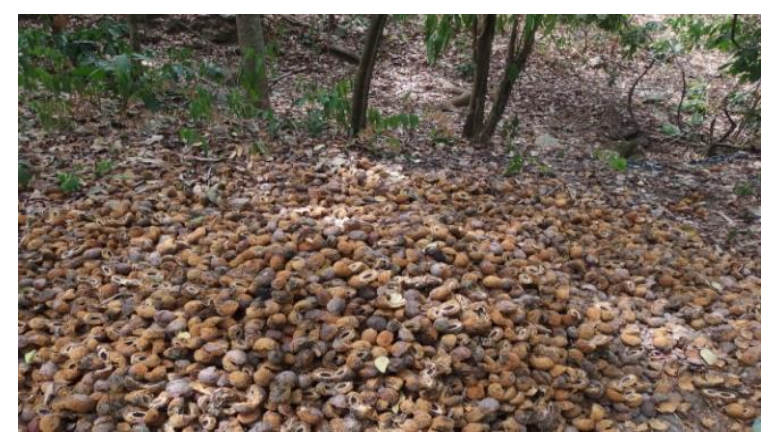

Photo 1: Harvest site of Detarium senegalense seed in Fazao park.

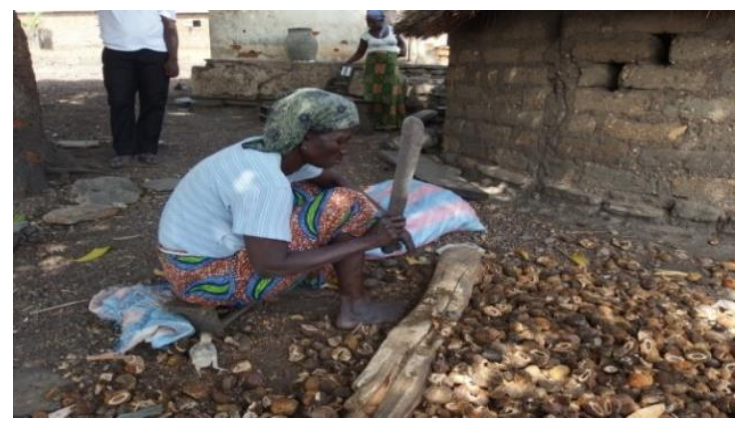

Photo 2: Decortication of Detarium senegalense fruit in the village of Fazao Malfakassa. 


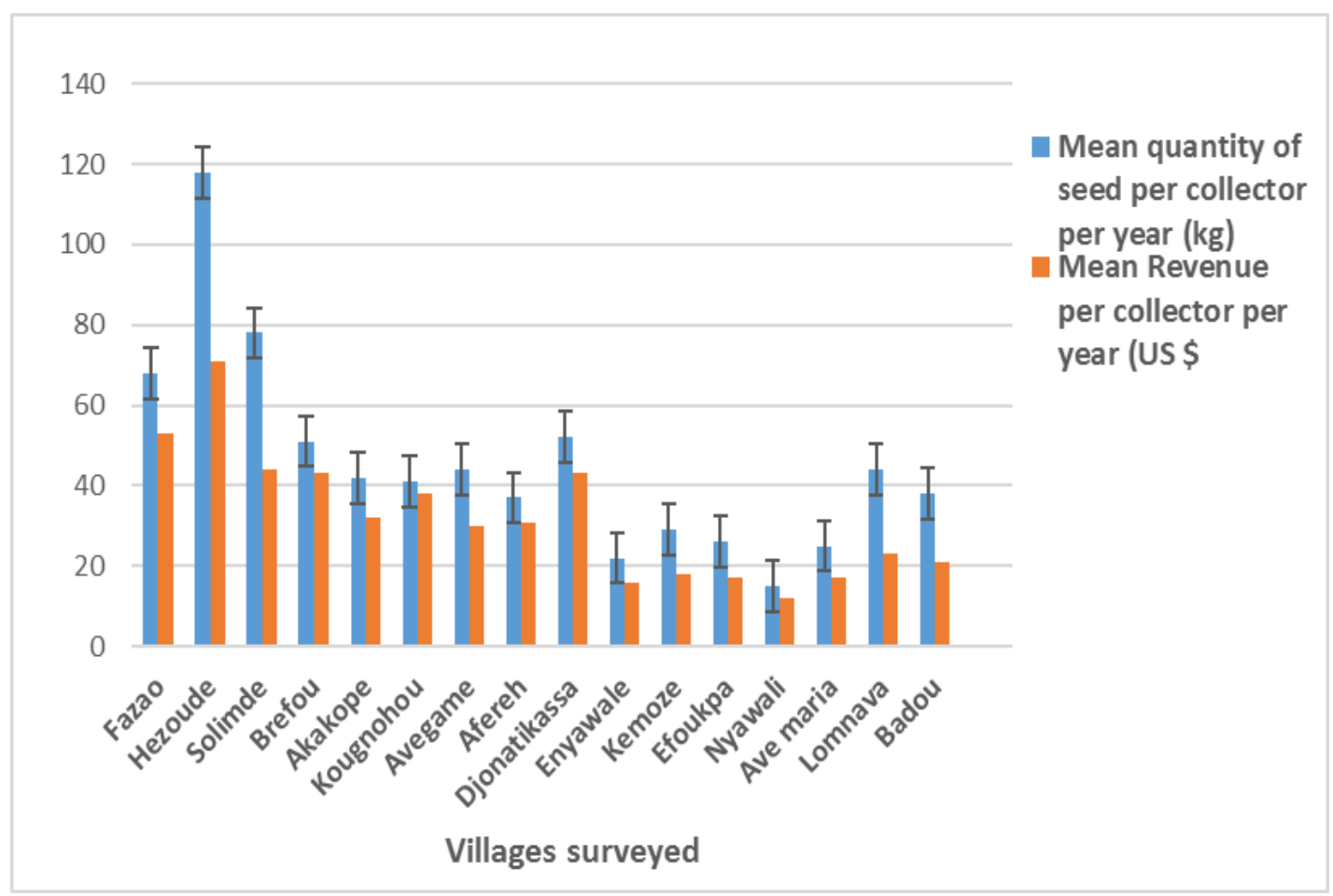

Figure 3: Mean quantity of seeds harvested and average annual income from the sale of Detarium senegalense seeds by collector.

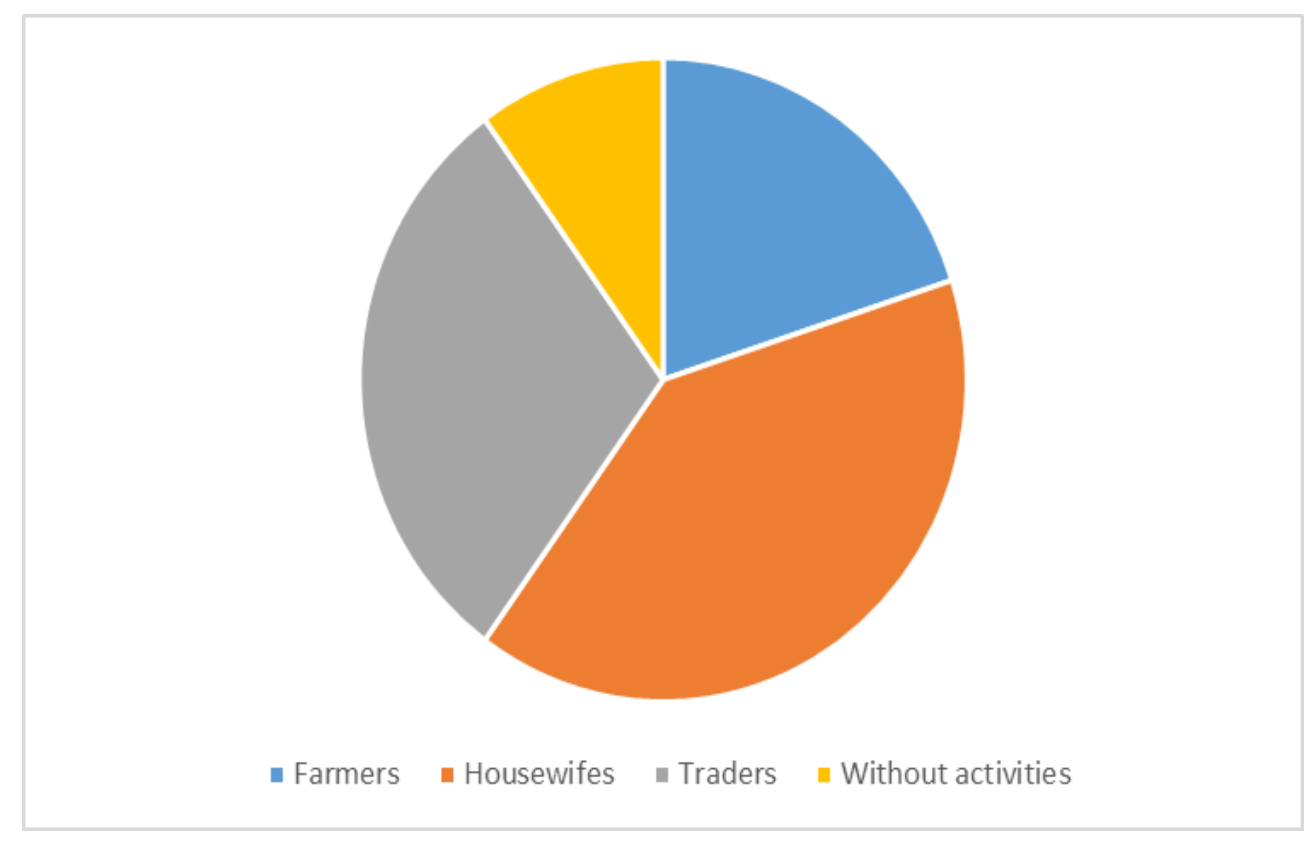

Figure 4: Mains activities of actors involved in Detarium senegalense seeds collecting. 


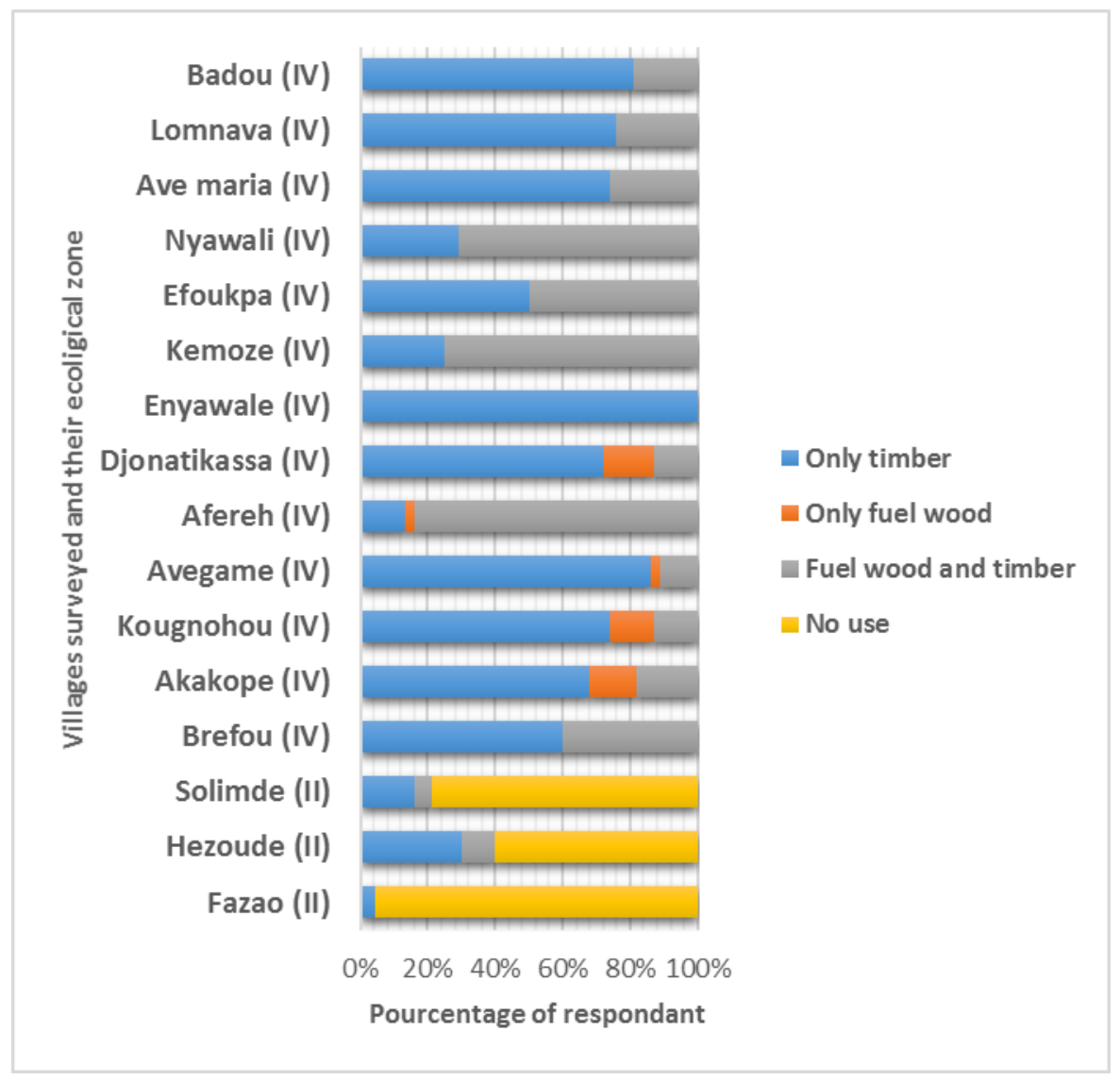

Figure 5: Use of Detarium senegalense tree in differents surveyed localities: (IV) stand for ecological zone IV; (II) stand for ecological.

\section{DISCUSSION}

\section{Contribution of Detarium senegalense seeds to the improvement of rural population living conditions}

The amount of seeds collected is important in the villages surrounding the National Fazao Park (zone II). This is probably because these villages are isolated and have few sources of income. This result matches those of the study by Malleson et al. (2014) who shown that households located in isolated areas are the most dependent on income from NTFPs, as they represent one of the few income generating opportunities in these areas. Heubes et al. (2012) has demonstrated that in a region where alternative income is virtually absent, especially for women, NTFPs harvesting activities help families to sustain themselves.
The results of this study confirm this observation. The sale of Detarium senegalense seeds is a source of cash income for collectors. It should be noted as presented in the results that neither fruits nor seeds are consumed locally in Togo. Even if the income from the sale of seeds is low, it contributes to the economy of poor households. Several other studies (Haarmeyer et al., 2013; Famuyide et al., 2013; Farinola et al., 2014; Heubes et al., 2012) have shown the economic importance of NTFPs, such as those derived from Arthocarpus sp., Canarium schweinfurthii, Dacryodes edulis, Ricinodendron heudelotii, Gambeya africana) both in terms of subsistence and income. Detarium senegalense seeds are sold only three (3) months per year; thus the income from the sale of the species per collector is 
less than the per capita gross annual income of US \$ 406 in ecological zone II and US \$ 350 in ecological zone IV. This is why the majority of those who sold seeds of the specie use to sell it with other forest products, such as Parkia biglobosa and Vitellaria paradoxa (shea butter) (Atato et al., 2010). According to Malleson et al. (2014), the income contribution of NTFPs, and the role its play in providing a safety-net, will remain important both to the poorest rural households who may not be able to access new economic opportunities and may need to fall back on NTFPs income. The sale of Detarium senegalense seeds is dominated by women. The high rate of women is explained by the fact that they are the main and most frequent collectors of forest products (e.g., firewood, non-timber forest products) (Mwangi et al., 2011). Also, Ahenkan and Boon (2011) shown that sex plays an important role in the commercialization of NTFPs in West Africa, with women being the majority in this activity. The results of this study thus confirm the importance of NTFPs like Detarium senegalense to the local population in Togo.

\section{Impact of Detarium senegalense exploitation and issues related to sustainability}

The forest inventories carried out per Dangbo, (2015) in the same area have shown that there is a low rate of regeneration Detarium senegalense in the forest area. From this study it can be deduced, for example, that the exploitation of seeds and wood of Detarium senegalense would have a negative impact on the regeneration capacity of the species. A study of Peres et al. (2003) shown that studying the impact of fruit harvesting is important for species with seed reproduction such as Detarium senegalense. Their excessive harvest can have a negative impact on the sustainability of these species, especially in the long term. Gaoue and Ticktin (2010) have shown how the biological responses of NTFP species can vary. It depends on several factors, namely the part of the plant that is harvested, the ecological conditions and the harvesting practices. The harvest is systematically done by the collection of mature fruits from trees measuring 15 to $30 \mathrm{~m}$ high. As a result, Detarium senegalense that grows up near forests is becoming rare in some areas, such as Badou. Today, people have to walk several kilometers to remote natural forest areas to find Detarium senegalense trees. Loubelo (2012) has shown that harvesting of mature fruit is detrimental to the harvested species if fruit collection is systematic and regular. This can reduce the chance of regeneration of new individuals and affect specific dynamics (Loubelo, 2012). The results of the present study confirm this observation. In addition, the surveyed population has a very limited notion of the sustainability or domestication of species. According to the majority of the population, resources of the forest are inexhaustible, even if they have to be picked up at very distant places of the village. Loubelo (2012) noted the same population reaction when he studied the impact of nontimber forest products on the household economy and food security in Congo. More than $50 \%$ of the respondents are waiting for the help of the State to make them aware of the domestication of this species and to offer them, if possible, the seedlings of the species to be planted.

\section{Future conservation and management strategies domestication}

Long-term management of Detarium senegalense individual is necessary to improve the livelihoods of the local population. To this end, effective awarenessraising among local population for the protection and domestication of the species could enable its future preservation (Sourou et al., 2016). Therefore, further studies should be done on the domestication of the species as well as silvicultural tests of reproduction and germination. For a better evaluation of the different actors involved in the Detarium senegalense value chain, socio-economic surveys should be done in Nigeria and Benin. This survey will allow to evaluate the profit margin of the various actors involved in the value chain. 


\section{Conclusion}

This study has described the socioeconomic value of Detarium senegalense for the rural population in Togo. Detarium senegalense can potentially contribute in a specific period of the year (tree month) to the economy and livelihoods of the rural population through generating cash income by the sale of seeds collected in the wild. The intensity of the harvest of Detarium senegalense seeds however can pose problems of its sustainable management. Priority must be given to secure the presence of the species in rural and forest areas and through domestication in agroforestry fields or as enrichment in degraded forest patches. Indeed, the sustainable management of Detarium senegalense is important because of their value as a sustainable source of subsistence income. Thus, it is necessary to support the improvement of the methods of sustainable harvest of the species. The challenge is how to integrate communities, ecology, forestry, law, economics and decentralization into the management of NTFPs in general and Detarium senegalense in particular. The success of this process will depend on all actors, including policy makers, technicians, local people, researchers, extension agencies and funding agencies.

\section{COMPETING INTERESTS}

The authors declare that they have no competing interests.

\section{AUTHORS' CONTRIBUTIONS}

KK and JB designed the research proposal. FAD realized the field work and KA contributed to the writing of the manuscript.

\section{REFERENCES}

Adjossou K. 2009. Diversité, structure et dynamique de la végétation dans les fragments de forêts humides du Togo: les enjeux pour la conservation de la biodiversité. $\mathrm{PhD}$ thesis, University of Lome. p.190.

Agbelade A, Onyekwelu J. 2013. Poverty alleviation through optimizing the marketing of Garcinia kola and Irvingia gabonensis in Ondo State, Nigeria. ISRN

Forestry.

DOI:

http://dx.doi.org/10.1155/2013/376247.

Ahenkan A, Emmanuel B. 2011. Improving the supply chain of non-timber forest products in Ghana. In Supply Chain Management-New Perspectives, IntechOpen, Renko S. (ed). University of Zagreb, Croatia

Ambé G. 2001. Les fruits sauvages comestibles des savanes guinéennes de Côte-d'Ivoire: état de la connaissance par une population locale, les Malinké. In Biotechnologie, Agronomie, Société et Environnement, Delgado F (ed). Pérou; 43-58

Atato A, Wala A, Batawila K, Woegan A, Akpagana K. 2010. Diversité des fruitiers ligneux spontanés du Togo. Fruit Veg. Cereal Sci. Biotechnol, 4(1): $1-9$.

Ayessou N, Ndiaye C, Cisse M, Gueye M, Sakho M, Dornier M. 2014. Nutrient composition and nutritional potential of wild fruit Dialium guineense. Journal of Food Composition and Analysis, 34 (2): 186-191.

DOI: https://doi.org/10.1016/j.jfca.2014.01.00 2.

Balde S, Ayessou N, Gueye M, Ndiaye B, Sow A, Cisse O, Diop C. 2019. Investigations ethnobotaniques de Momordica charantia Linn (Cucurbitaceae) au Sénégal. International Journal of Biological and Chemical Sciences, 13(1): 466-47. DOI: https://dx.doi.org/10.4314/ijbcs.v13i1.37

Bayeli G, Joiris V, Lohandjola G, Habari J. 2019. Contribution à l'étude des plantes médicinales utilisées dans le traitement des abcès dans le territoire de Bikoro, province de l'Equateur en RDC. International Journal of Biological and Chemical Sciences, 13(1): 353-368. DOI:

https://dx.doi.org/10.4314/ijbcs.v13i1.28

Belcher B, Vantomme P. 2003. "What isn't an NTFP? ». The International Forestry Review, 5(2): 161-168. DOI: 
https://doi.org/10.1505/ifor.5.2.161.1740 8.

Dangbo F. 2015. Detarium senegalense: rôle socio-économique et durabilité écologique au Togo. Master thesis, Bern University of Applied Science (HAFL), Switzerland, p 82.

Diop N, Ndiaye A, Cisse M, Dieme O, Dornier M, Sock O. 2010. «Le ditax (Detarium senegalense JF Gmel.): principales caractéristiques et utilisations au Sénégal ». Fruits, 65(5): 293-306. DOI:

https://doi.org/10.1051/fruits/2010025

Famuyide O, Adebayo K, Bolaji-Olutunji F, Awe A, Owoeye D, Awodele O, Adeyemo A. 2013. Assessment and sustainable management of non-timber forest products used as food and medicine among urban dwellers in Oyo State, Nigeria. Journal of Horticulture and Forestry, 5(11): 186-193. DOI: https://doi.org/10.5897/JHF2013.0324.

Farinola L, Famuyide O, Nosiru O, Ogunsola A. 2014. Survey of identified Non Timber Forest Products and their role in the rural livelihood of inhabitants of Omo Forest Reserve, Ogun State. International Journal of Agriculture and Forestry, 4(4): 317-324. DOI: https://doi.org/10.5923/j.ijaf.20140404.0 9.

Gaoue O, Orou G, Ticktin T. 2010. Effects of harvest of nontimber forest products and ecological differences between sites on the demography of African mahogany. Conservation Biology, 24(2): 605-614. DOI: https://doi.org/10.1111/j.15231739.2009.01345.x.

Haarmeyer D, Schumann K, BernhardtRömermann M, Wittig R, Thiombiano A, Hahn K. 2013. Human impact on population structure and fruit production of the socio-economically important tree Lannea microcarpa in Burkina Faso. Agroforestry Systems, 87(6): 1363-1375. DOI: https://doi.org/10.1007/s10457013-9644-7.

Heubes J, Heubach K, Schmidt M, Wittig R, Zizka G, Nuppenau E, Hahn K. 2012.
Impact of future climate and land use change on non-timber forest product provision in Benin, West Africa: Linking niche-based modeling with ecosystem service values. Economic Botany, 66(4): 383-397.

DOI: https://doi.org/10.1007/s12231-0129216-1.

Kebenzikato A, Wala K, Dourma M, Atakpama W, Dimobe K, Pereki H, Batawila K, Akpagana K. 2014. Distribution et structure des parcs à Adansonia digitata L. (baobab) au Togo (Afrique de l'Ouest). Afrique Science: Revue Internationale des Sciences et Technologie, $\mathbf{1 0}$ (2).

Kothari R. 2004. Research Methodology: Methods and Techniques. New Age International; $401 \mathrm{p}$.

Loubelo E. 2012. Impact des produits forestiers non ligneux (PFNL) sur l'économie des ménages et la sécurité alimentaire: cas de la République du Congo. PhD Thesis, Université Rennes 2, $210 \mathrm{p}$.

Lykke A. 2000. Local perceptions of vegetation change and priorities for conservation of woody-savanna vegetation in Senegal. Journal of Environmental Management, $\mathbf{5 9 ( 2 ) : ~}$ 107-120. DOI: https://doi.org/10.1006/jema.2000.0336.

Malleson R, Asaha S, Egot M, Kshatriya M, Marshall E, Obeng-Okrah K, Sunderland T. 2014. Non-timber forest products income from forest landscapes of Cameroon, Ghana and Nigeria-an incidental or integral contribution to sustaining rural livelihoods? International Forestry Review, 16(3): 261-277. DOI: https://doi.org/10.1505/14655481481257 2449

McLafferty S. 2003. Conducting questionnaire surveys ». Key Methods in Geography, 87-100.

Mwangi E, Meinzen-Dick R, Sun Y. 2011. Gender and sustainable forest management in East Africa and Latin America. Ecology and Society, 16(1). 
DOI: https://doi.org/10.5751/es-03873160117

Neumann R, Hirsch E. 2000. Commercialisation of non-timber forest products: review and analysis of research. Cifor. DOI: https://doi.org/10.17528/cifor/000723

Peres C, Baider C, Pieter A, Lúcia H, Karen A, Daisy A, Rafael P, Luciana L, Eduardo R, Cornejo F, Gribel R, Glenn H, Kanashiro M, Coventry P, Douglas W, Andrew R, Robert P. 2003. Demographic threats to the sustainability of Brazil nut exploitation. Science, 302 (5653): 2112-2114. DOI: https://doi.org/10.1126/science.1091698.

Repubique du Togo. 2013. SCAPE (Stratégie de Croissance Accélérée et de Promotion de l'Emploi 2013 - 2017). Togo, 136 p.

Sounon K, Aho E, Lesse P, Ickowicz A, Messad S, Lesnoff M, Houinato $M$.
2019. Evaluation de la valeur économique directe de l'élevage bovin au nord-Bénin. International Journal of Biological and Chemical Sciences, 13(1): $\quad 8-17 . \quad$ DOI: https://doi.org/10.4314/ijbcs.v13i1.2

Sourou B, Yabi J, Ouinsavi C, Sokpon N. 2016. Importance socio-économique de la prune rouge (Haematostaphis barteri Hook F.) au Bénin. International Journal of Biological and Chemical Sciences, $\quad$ 10(1): 326-343. DOI: http://dx.doi.org/10.4314/ijbcs.v10i1.25

Timko J, Waeber P, Kozak R. 2010. The socio-economic contribution of nontimber forest products to rural livelihoods in Sub-Saharan Africa: knowledge gaps and new directions. International Forestry Review, 12(3): 284-294.

DOI: https://doi.org/10.1505/ifor.12.3.284. 